\title{
Hydrological recovery in two large forested watersheds of southeastern China: the importance of watershed properties in determining hydrological responses to reforestation
}

\author{
Wenfei Liu ${ }^{1}$, Xiaohua Wei ${ }^{2}$, Qiang Li $^{2}$, Houbao Fan ${ }^{1}$, Honglang Duan ${ }^{1}$, Jianping Wu ${ }^{1}$, Krysta Giles-Hansen ${ }^{2}$, and \\ Hao Zhang ${ }^{1}$ \\ ${ }^{1}$ Institute of Ecology and Environmental Science, Nanchang Institute of Technology, Nanchang, China \\ ${ }^{2}$ Department of Earth and Environmental Sciences, University of British Columbia (Okanagan campus), 1177 Research Road, \\ Kelowna, British Columbia, V1V 1V7, Canada
}

Correspondence to: Xiaohua Wei (adam.wei@ubc.ca)

Received: 29 June 2016 - Published in Hydrol. Earth Syst. Sci. Discuss.: 4 July 2016

Revised: 27 September 2016 - Accepted: 30 October 2016 - Published: 1 December 2016

\begin{abstract}
Understanding hydrological responses to reforestation is an important subject in watershed management, particularly in large forested watersheds $\left(>1000 \mathrm{~km}^{2}\right)$. In this study, we selected two large forested watersheds (Pingjiang and Xiangshui) located in the upper reach of the Poyang Lake watershed, southeastern China (with an area of 3261.4 and $1458 \mathrm{~km}^{2}$, respectively), along with long-term data on climate and hydrology (1954-2006) to assess the effects of large-scale reforestation on streamflow. Both watersheds have similar climate and experienced comparable and dramatic forest changes during the past decades, but with different watershed properties (e.g., the topography is much steeper in Xiangshui than in Pingjiang), which provides us with a unique opportunity to compare the differences in hydrological recovery in two contrasted watersheds. Streamflow at different percentiles (e.g., 5, 10, 50 and 95\%) were compared using a combination of statistical analysis with a year-wise method for each watershed. The results showed that forest recovery had no significant effects on median flows $\left(Q_{50} \%\right)$ in both watersheds. However, reforestation significantly reduced high flows in Pingjiang, but had limited influence in Xiangshui. Similarly, reforestation had significant and positive effects on low flows $\left(Q_{95} \%\right)$ in Pingjiang, while it did not significantly change low flows in Xiangshui. Thus, hydrological recovery is limited and slower in the steeper Xiangshui watershed, highlighting that watershed properties are also important for determining hydrological responses to
\end{abstract}

reforestation. This finding has important implications for designing reforestation and watershed management strategies in the context of hydrological recovery.

\section{Introduction}

Water quantity is of the utmost importance for ecosystem functions, and economic and social development. In forested watersheds, forests play an important role in hydrological processes and their associated ecological functions. Numerous studies have indicated that forest changes (e.g., reforestation or deforestation) can significantly affect hydrological processes (Jackson et al., 2005; Clinton, 2011; Ford et al., 2011; Iroumé and Palacios, 2013; Liu et al., 2015a). However, there are large variations in hydrological responses to forest changes, probably depending on climate and watershed characteristics. Understanding those variations can greatly improve our understanding of the possible mechanisms responsible for hydrological responses and support our management decisions on water and watershed protections.

In large forested watersheds, various factors including climate, land cover, forest changes, and watershed properties can influence streamflow (Anderson and Kneale, 1982). While previous research mainly focused on how climate and forest cover change affect hydrology, limited research has been conducted to examine the role of watershed proper- 
ties in hydrological responses. However, watershed properties can be an important factor in determining hydrological responses (Allan, 2004; Poff et al., 2006a, b; Price et al., 2011; Troch et al., 2013; Zhou et al., 2015). For example, Zhang and Wei (2014a) studied two neighboring watersheds $\left(3420 \mathrm{~km}^{2}\right)$ and Willow $\left(2860 \mathrm{~km}^{2}\right)$ in British Columbia, Canada, and found that their contrasted hydrological responses to forest harvesting are mainly related to the difference in their topography and landform complexities. Zhou et al. (2015) also found that watershed characteristics such as watershed slope and size play an important role in hydrological responses in their metadata analysis from 168 global studies on large forested watersheds. Clearly, more case studies are needed to assess how watershed properties affect hydrological responses in the context of the other key drivers (e.g., climate and forest changes).

Poyang Lake of Jiangxi Province, which directly flows into Yangtze River, is the largest freshwater lake $\left(3500 \mathrm{~km}^{2}\right)$ in China. It is fed by five rivers including Gan, Xin, Xiu, Rao and $\mathrm{Fu}$. Poyang Lake provides significant water resources, wildlife habitats (especially for migratory birds), and economic value (Guo et al., 2008; Huang et al., 2012; Schmalz et al., 2014). However, Poyang Lake Basin experienced severe forest disturbance from the 1960s to the 1980s. Such intense land-use changes resulted in severe environmental degradation. To restore the degraded environment, several ecological restoration and protection programs (e.g., large-scale reforestation) have been implemented since 1980s (Wei et al., 2008). As a result, the forest coverage has increased significantly in the past few decades. Because Poyang Lake Basin plays a strategic role in environmental protection and economic development in the province as well as in the lower reach of Yangtze River Basin, assessing the ecological effects of those large-scale stewardship programs would be crucial for determining the effectiveness of ecological recovery and for guiding future program design. To our knowledge, several studies had been conducted to assess how large-scale reforestation programs might affect soil erosion and forest carbon processes, but no research has been conducted to assess hydrological recovery under those large-scale stewardship programs.

Two large neighboring watersheds including Pingjiang watershed $\left(2689.20 \mathrm{~km}^{2}\right)$ and Xiangshui watershed $\left(1758 \mathrm{~km}^{2}\right)$, which have similar forest change levels but different watershed properties in the upper reach of the Poyang Lake watershed, were chosen for the study. Hydrological variables such as streamflow at different percentiles (e.g., high flows and low flows) were examined for each watershed, and their differences were then compared. The objectives of this study were: (1) to assess how stream flows (high and low flows) respond to forest changes at each watershed; (2) to compare their hydrological responses between two different watersheds; and (3) to discuss implications for watershed management.
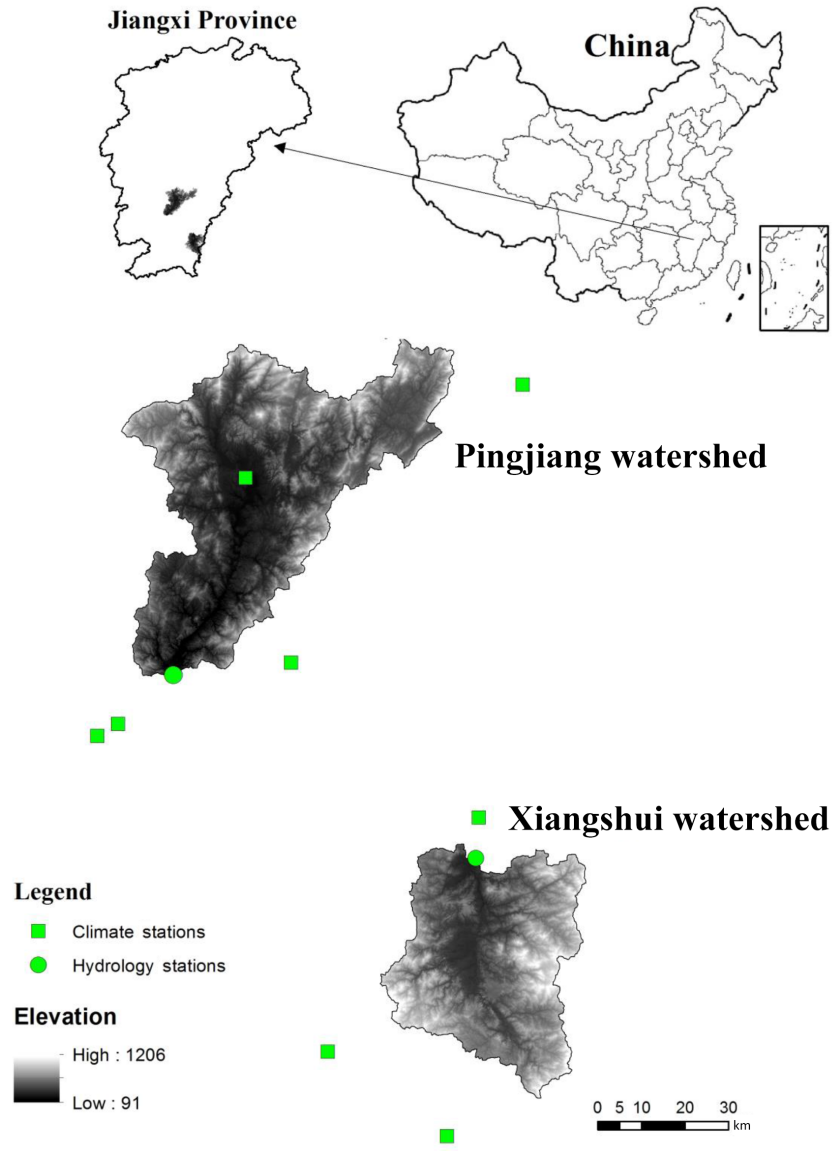

Figure 1. The location of the Pingjiang and Xiangshui watersheds.

\section{Watershed descriptions and data}

\subsection{Watershed characteristics}

The Pingjiang and Xiangshui watersheds feed into the Gan River, the largest tributary of the Poyang Lake watershed (Fig. 1). The drainage areas of the two are 2689 and $1758 \mathrm{~km}^{2}$, respectively. The two watersheds are located in the hilly region of Jiangxi Province, China. The Xiangshui watershed is characterized by a steeper topography than the Pingjiang watershed, with the former having higher slopes covering $23.9 \%$ of the watershed area (from 30 to $50^{\circ}$ ) while the latter has only $4.6 \%$ for the same slope class (Table 1 ). Soils are mountain red soil and yellow-red soil with sandy loam texture in both watersheds. The main characteristics of two watersheds are presented in Table 2 .

The two watersheds studied are within the subtropical monsoon zone and have a similar precipitation regime. The average annual precipitations are 1575 and $1611 \mathrm{~mm}$ in Piangjiang and Xiangshui watersheds, respectively, of which most falls from April to June (the wet season, about $50 \%$ ) and less from September to November (the dry season, about $12 \%$ ). The average annual temperatures are 18.9 and 

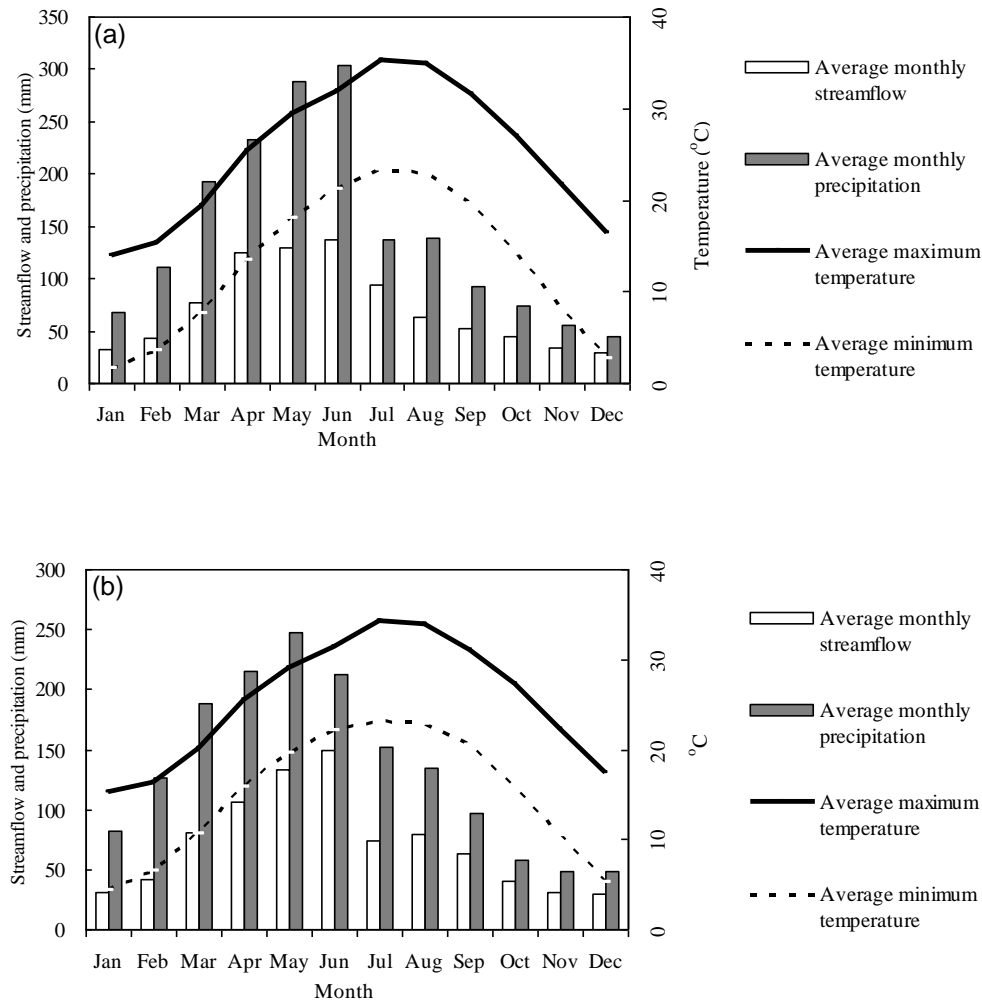

: precipitation

Average maximum

emperature

- - - Average minimum temperature

Figure 2. Average monthly streamflow, precipitation, minimum temperature and maximum temperature from 1957 to 2006 for the Pingjiang watershed (a) and the Xiangshui watershed (b).

Table 1. Averaged slopes in two watersheds studied (Pingjiang and Xiangshui).

\begin{tabular}{lrrrrrr}
\hline Watershed & \multicolumn{6}{c}{ Percentage of watershed area (\%) } \\
\cline { 2 - 7 } & $\begin{array}{r}\text { Slope } \\
>35^{\circ}\end{array}$ & $25-35^{\circ}$ & $15-25^{\circ}$ & $8-15^{\circ}$ & $3-8^{\circ}$ & $<3^{\circ}$ \\
& & & & & & \\
\hline Pingjiang & 4.60 & 52.82 & 2.40 & 29.44 & 6.63 & 4.11 \\
Xiangshui & 23.85 & 26.99 & 9.20 & 33.05 & 6.17 & 6.91 \\
\hline
\end{tabular}

$19.2^{\circ} \mathrm{C}$, respectively. The maximum temperature in summer and the minimum temperature in winter are 37 and $0{ }^{\circ} \mathrm{C}$, respectively (Fig. 2).

The majority of annual peak flows correspond to rainfall events in two watersheds. In Pingjiang watershed, annual peak flows are between 137 and $870 \mathrm{~m}^{3} \mathrm{~s}^{-1}$ per $1000 \mathrm{~km}^{2}$, while they are between 108 and $728 \mathrm{~m}^{3} \mathrm{~s}^{-1}$ per $1000 \mathrm{~km}^{2}$ in Xiangshui watershed. Annual minimum flows range from 2.0 to $11.6 \mathrm{~m}^{3} \mathrm{~s}^{-1}$ per $1000 \mathrm{~km}^{2}$ in Pingjiang watershed and are 0.9 to $11.4 \mathrm{~m}^{3} \mathrm{~s}^{-1}$ per $1000 \mathrm{~km}^{2}$ in the Xiangshui watershed. Average annual mean flows are 848 and $858 \mathrm{~m}^{3} \mathrm{~s}^{-1}$, respectively.

The major land cover types include forest, agriculture, grass, and urban and construction land. Subtropical evergreen broad-leaved forest is the major climax vegetation type in the watersheds studied, including Castanopsis fabri, Castanopsis sclerophylla, Schima superba, Sassafras tzumu and Castanopsis fissa. In contrast, major plantation forests are Pinus massoniana, Cunninghamia lanceolata, Camellia oleifera Abel and Phyllostachys heterocycla.

\subsection{Data}

Stream flow data area available from 1957 to 2006 for both watersheds. The hydrometric stations for data collection are part of the Chinese National Hydrometric Network (Fig. 1). Climate data are also available for the same length (19572014) for each watershed (five climate stations for Pingjiang and three for Xiangshui), and include the records of daily maximum, mean, and minimum temperatures and daily precipitation. The averaged watershed-based precipitation estimates were derived by the Thiessen polygon method.

\section{Methods}

\subsection{Leaf area index (LAI) and forest coverage}

The Global Land Surface Satellite (GLASS) LAI data were used as the proxy of forest coverage in the watersheds studied. The GLASS LAI product provides the global LAI at the spatial resolution of $0.05^{\circ}$ and temporal resolution of 8 days 
Table 2. A summary of watershed characteristics for the Pingjiang and Xiangshui watersheds.

\begin{tabular}{lll}
\hline Metrics & Pingjiang & Xiangshui \\
\hline Drainage area $\left(\mathrm{km}^{2}\right)$ & 2689.20 & 1758 \\
Average elevation $(\mathrm{m})$ & 298 & 429 \\
Soil type & Mountain red soil and yellow-red soil & Mountain red soil and yellow-red soil \\
Annual mean precipitation $(\mathrm{mm})$ & 1575 & 1611 \\
Annual mean temperature $\left({ }^{\circ} \mathrm{C}\right)$ & 18.9 & 19.2 \\
Annual mean ET $(\mathrm{mm})$ & 879.2 & 936.8 \\
Annual mean flow $(\mathrm{mm})$ & 848 & 858 \\
Runoff coefficient & 0.54 & 0.53 \\
Maximum flow $\left(\mathrm{m}^{3} \mathrm{~s}^{-1}\right)$ & 1530 & 1280 \\
Minimum flow $\left(\mathrm{m}^{3} \mathrm{~s}^{-1}\right)$ & 5.5 & 2.3 \\
BioGeoClimatic zone & Subtropic monsoon & Subtropic monsoon \\
Forest type & Subtropical evergreen broadleaf forest and conifer forest & Subtropical evergreen broadleaf forest and conifer forest \\
Dominant disturbance type & Logging & Logging \\
Hydrometric station & Hanlinqiao & Mazhou \\
\hline
\end{tabular}

for the period of 1981 to 2014 (http://www.bnu-datacenter. $\mathrm{com} /$ ). The GLASS LAI data have been validated through the field measurements to ensure data quality for long-term studies in vegetation changes (Liang and Xiao, 2012; Xiao et al., 2014). The growing season LAI values were based on the LAI values from April to October for each year. The watershed-based LAI values were derived by averaging the LAI data for the pixels where more than $50 \%$ of their pixel areas falls inside the watershed boundaries.

Forest change is the main type of land-use change in the watersheds we studied. Because the complete records of annual deforestation and reforestation areas are unavailable, forest coverage and LAI data were used to indicate historic forest changes during the study period (1957-2006). As shown in Fig. 3, forest cover was greatly reduced in the period 1965-1984 due to large-scale forest disturbance (e.g., deforestation). Since then, forest cover was significantly increased from about $30 \%$ in the 1980 s to $70 \%$ in 2006 in both watersheds due to implementation of the reforestation projects (1990-2006) (Fig. 3). Thus, the entire study period was divided into the forest disturbance period (1957-1985) and the forest recovery period (19902006).

\subsection{Median, high, and low flows}

In this study, FDCs (flow-duration curves) were applied to define high, median, and low flows. FDCs represent the percent of time streamflow for any given value exceeded or equaled in a period of record (Vogel and Fennessey, 1994). In this study, median flows are defined as the flows that exceed or are equal to $Q_{50 \%}$. High flows are defined as the flows that exceed or are equal to $Q_{5} \%$ and $Q_{10 \%}$ ( $Q_{5} \%$ : flows exceeding $5 \%$ of the time in a given year and $Q_{10 \%}$ : flows exceeding $10 \%$ of the time in a given year), while low flows are defined as the flows that are equal to or less than $Q_{95} \%$ ( $Q_{95 \%}$ : flows exceeding $95 \%$ of the time in a given year) (Zhang and Wei, 2014b; Liu et al., 2015b).
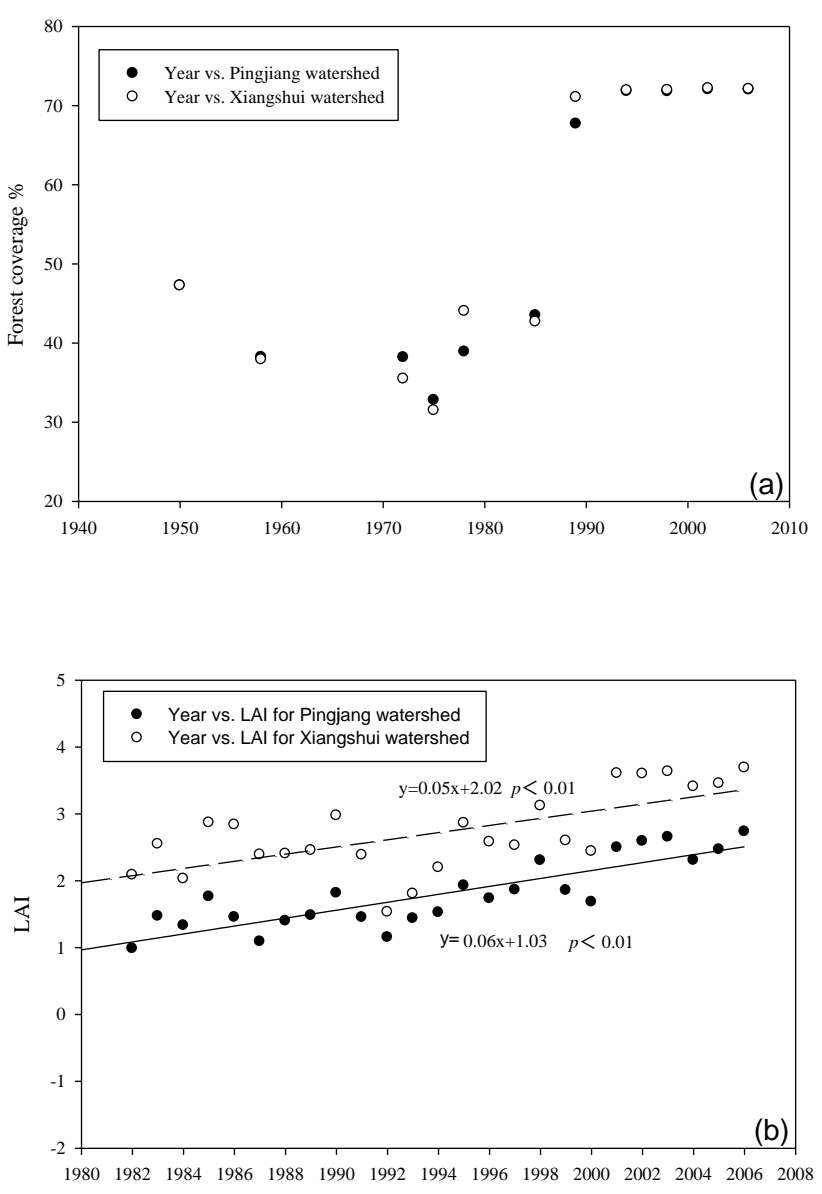

Figure 3. Forest cover (\%) (a) and Leaf Area Index (LAI) (b) from 1982 to 2006 in the Pingjiang and Xiangshui watershed. 
In order to assess the impacts of forest changes on high, median, and low flows, the effect of climate variability must be eliminated. For a single watershed, pair-wise comparisons can be used to address this issue (Levy, 1975; Broomell et al., 2011; Zhang and Wei, 2014b; Liu et al., 2015b; Eastwood et al., 2016). Because high flows are mainly caused by rainfall events, we can find some similar and comparable rainfall events between the reforestation and deforestation periods with similar $R_{5} \%$ and $R_{10 \%}$, respectively ( $R_{5} \%$ : rainfall exceeding $5 \%$ of the time in a given year and $R_{10} \%$ : rainfall exceeding $10 \%$ of the time in a given year). However, low and median flows are significantly correlated with annual rainfall, annual maximum temperature, and annual mean temperature (Tables 3 and 4). Therefore, paired years between the reforestation and deforestation periods were selected for analysis of low and median flows (Tables S1 and S2 in the Supplement). More details about this method can be found in Zhang and Wei (2014a) and Liu et al. (2015b).

\subsection{Estimation of recession constants}

Recession constant is a useful indicator reflecting the characteristics of the study basin (Barnes, 1939; Ge et al., 2014). For a watershed, the difference in recession constants of streamflow with similar climate conditions between different periods can be ascribed to the effect of land-cover change, while the difference in recession constants of streamflow between the two watersheds studied, under similar climate conditions, can be ascribed to the effect of different water properties on streamflow.

In this paper, the classical recession curve based on a genetic algorithm (GA) was adopted to study and analyze the daily runoff (Eqs. 1 and 2).

$Q_{t}=Q_{0} e^{-\beta t}$

$\beta=\left(\ln Q_{0}-\ln Q_{t}\right)$

Here, $Q_{0}$ is the initial discharge ( $\left.t=0\right), Q_{t}$ is the discharge at a later time (usually in days), and $\beta$ is the recession constant.

The paired-wise approach was also used to assess the effects of forest changes on recession constants. Because high flows are mainly caused by rainfall events (e.g., storm events) in the study area, we can select similar and comparable rainfall events between the reforestation and the disturbance periods (Table S3 in the Supplement).

\section{Results}

\subsection{High flows' response to forest changes}

As shown in Fig. 4a, the average magnitude of high flows $\left(Q_{5} \%\right)$ in the reforestation period $\left(327.7 \mathrm{~m}^{3} \mathrm{~s}^{-1}\right)$ was significantly lower $(p<0.01)$ than that in the deforestation period $\left(534.9 \mathrm{~m}^{3} \mathrm{~s}^{-1}\right)$ in the Pingjiang watershed. Similarly, the average magnitude of high flows $\left(Q_{10 \%}\right)$ in the reforestation

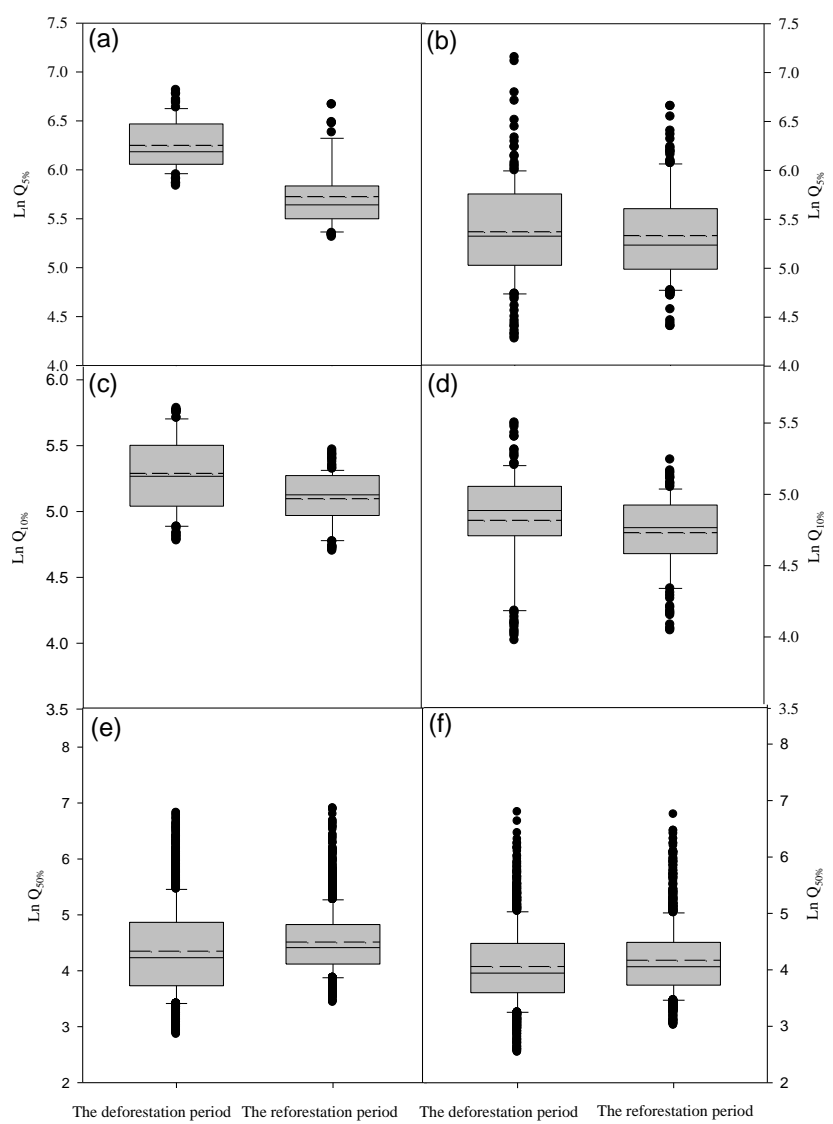

Figure 4. High flows and median flows for the selected pairs in the deforestation and reforestation periods: (a) high flows $\left(Q_{5 \%}\right)$ for the Pingjiang watershed; (b) high flows $\left(Q_{5} \%\right)$ for the Xiangshui watershed; (c) high flows $\left(Q_{10}\right)$ for the Pingjiang watershed; (d) high flows $\left(Q_{10 \%}\right)$ for the Xiangshui watershed; (e) Median flows $\left(Q_{50} \%\right)$ for the Pingjiang watershed; and (f) Median flows $\left(Q_{50} \%\right)$ for the Xiangshui watershed.

period $\left(164.4 \mathrm{~m}^{3} \mathrm{~s}^{-1}\right)$ was also significantly lower $(p<0.01)$ than that in the deforestation period $\left(198.7 \mathrm{~m}^{3} \mathrm{~s}^{-1}\right)$ in the Pingjiang watershed (Fig. 4c).

For the Xiangshui watershed, the average magnitude of high flows $\left(Q_{5} \%\right)$ in the reforestation period $\left(233.0 \mathrm{~m}^{3} \mathrm{~s}^{-1}\right)$ was lower than that in the deforestation period $\left(251.4 \mathrm{~m}^{3} \mathrm{~s}^{-1}\right)$ (Fig. 4b), but their difference was not statistically significant $(p=0.46)$. The average magnitude of high flows $\left(Q_{10 \%}\right)$ in the reforestation period $\left(118.0 \mathrm{~m}^{3} \mathrm{~s}^{-1}\right)$ was significantly lower $(p<0.05)$ than that in the deforestation period $\left(127.9 \mathrm{~m}^{3} \mathrm{~s}^{-1}\right)$ (Fig. 4d). Thus, reforestation significantly decreased high flows in the Pingjiang watershed, while such an effect is relatively limited in the Xiangshui watershed.

\subsection{Median flows' response to forest changes}

As shown in Fig. 4e and $\mathrm{f}$, the averaged magnitudes of median flows in the reforestation period (43.1 and $41.5 \mathrm{~m}^{3} \mathrm{~s}^{-1}$, respectively) showed no significant difference $(p=0.21$ 


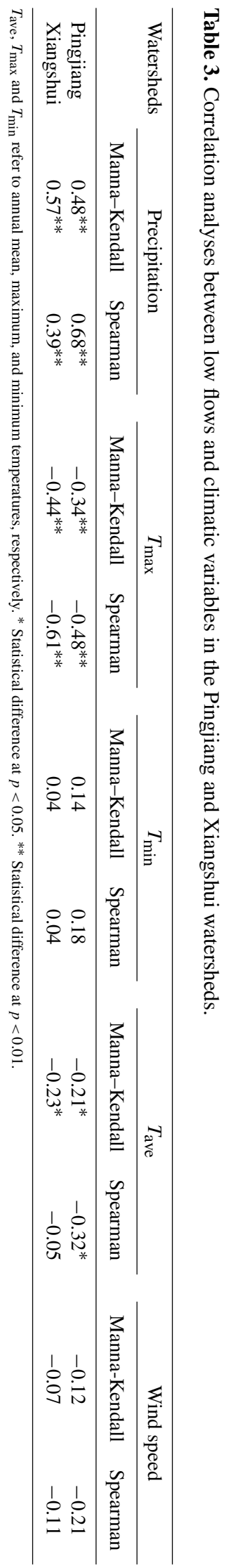

Hydrol. Earth Syst. Sci., 20, 4747-4756, 2016
Table 4. Canonical correlation analyses between hydrological variables (median and low flows) and climatic variables in the Pingjiang and Xiangshui watersheds.

\begin{tabular}{llcc}
\hline Watersheds & $\begin{array}{l}\text { Canonical correlation } \\
\text { analysis }\end{array}$ & Canonical $R$ & Significant \\
\hline Pingjiang & Precipitation, & 0.88 & $p<0.01$ \\
Xiangshui & $T_{\text {ave }}$ and $T_{\max }$ & 0.89 & $p<0.01$ \\
\hline
\end{tabular}

and 0.27 , respectively) to those in the deforestation period in Pingjiang and Xiangshui watersheds $\left(40.3\right.$ and $38.4 \mathrm{~m}^{3} \mathrm{~s}^{-1}$, respectively), indicating that reforestation had no significant effects on median flows $\left(Q_{50 \%}\right)$ in both watersheds.

\subsection{Low flows' response to forest changes}

As shown in Fig. 5a, the average magnitude of low flows in the reforestation period $\left(12.3 \mathrm{~m}^{3} \mathrm{~s}^{-1}\right)$ was significantly higher $(p<0.01)$ than that in the deforestation period $\left(8.7 \mathrm{~m}^{3} \mathrm{~s}^{-1}\right)$ in the Pingjiang watershed. In contrast, the average magnitude of low flows in the deforestation period did not significantly differ from that in the reforestation period (Fig. 5b) in the Xiangshui watershed. Thus, reforestation significantly increased low flows in the Pingxiang watershed but not in the Xiangshui watershed.

\subsection{Responses of recession constants to forest changes}

As shown in Fig. 5c and d, the averaged recession constant of streamflow in the reforestation period was significantly lower $(p=0.049)$ than that in the deforestation period in the Pingjiang watershed, while the difference was not significant $(p=0.52)$ in the Xiangshui watershed, suggesting that hydrological responses to reforestation is more sensitive in the Pingjiang watershed than in the Xiangshui watershed.

\section{Discussion}

Although the effects of reforestation on peak flows are still controversial (Gafur et al., 2003; Nadal-Romero et al., 2016; Liu et al., 2015a), a general conclusion is that increased forest coverage through reforestation can reduce high flows (Llorens et al., 1997; Gebrehiwot et al., 2010; Nadal-Romero et al., 2016). Our study found that reforestation can significantly decrease high flows, which can thereby reduce flood risks. Thus, our results are consistent with the general results found in other regions (e.g., Gafur et al., 2003; Bahremand et al., 2007; Tran et al., 2010). Our results are also supported by another study in a neighboring watershed (Meijiang) of the same region (Liu et al., 2015b) where the historic forest change is similar to those in our study. A common reason for reduced high flows after reforestation is that reforestation increases forest coverage and slowly improves soil conditions, 


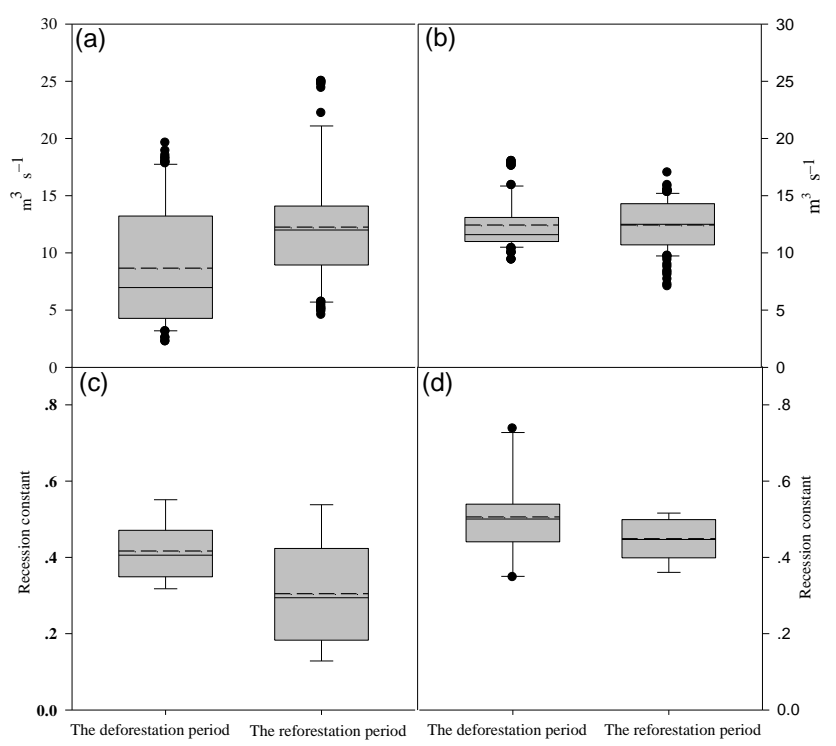

Figure 5. Low flows and recession constants of streamflow for the selected pairs in the deforestation and reforestation periods: (a) low flows for the Pingjiang watershed; (b) low flows for the Xiangshui watershed; (c) recession constants for the Pingjiang watershed; and (d) recession constants for the Xiangshui watershed.

which consequently enhances soil infiltration capacity and reduces high flows.

Our study showed that reforestation significantly increased low flows in the Pingjiang watershed. Although not statistically significant $(p=0.084)$, the low flows after reforestation in the Xiangshui watershed were also improved (Fig. 5b). Thus, reforestation had a positive role in low flows in the study watersheds. Our results are consistent with various reforestation studies, particularly in higher humidity environments (Buttle, 2011; Yao et al., 2012; Liu et al., 2015b). For example, Zhou et al. (2010) studied the effects of largescale reforestation on hydrology in the whole Guangdong province, and found that an increase of $30 \%$ forest cover played a positive role in redistributing water from the wet season to the dry season and, consequently, in increasing water yield in the dry season. The main reason for enhancing low flows from reforestation is that reforestation improves vegetation and soil conditions, and consequently improves soil infiltration and groundwater recharging, which have positive effects on low flows.

The responses of low flows to reforestation are inconsistent across different climate regimes. Lu et al. (2016) first estimated the effects of reforestation on groundwater resources using seven evapotranspiration models and suggested that China's unprecedented reforestation program would result in greatly decreased depth of groundwater in the arid and semiarid areas of northern China. A similar study conducted in the Loess Plateau of China also found a statistically significant $(p<0.1)$ reduction of $0.03 \mathrm{~mm}$ of groundwater per year from 1955 to 2010 due to implementation of large-scale re- forestation projects (Gao et al., 2015). The results from a paired watershed experiment in South Africa showed that low flows were reduced by half due to reforestation (Smith and Scott, 1992). A study analyzing the responses of streamflow to forest plantation expansion in six large river watersheds (from 94 to $1545 \mathrm{~km}^{2}$ ) of central-southern Chile indicated that reforestation had less effect on low water flows ( $Q_{80 \%}$ to $Q_{90 \%}$ ) in relatively drier soils (Iroumé and Palacios, 2013). However, in humid regions, increases in vegetation cover often lead to greater infiltration of rainfall into the soil, and as a result, increase water storages and low flows (Zhou et al., 2010). More case studies are needed before a general comparison between reforestation and low flows can be developed.

Although reforestation generally played a positive role in streamflow in our study area, there are large differences in the hydrological responses between the two study watersheds. As shown above, there are more significant effects on both high and low flows in the Pingiiang watershed than in the Xiangshui watershed. Since both watersheds have experienced similar historic forest change and climate, we believe that the difference in the responses of high and low flows were mainly due to the difference in their watershed properties. A close examination of their watershed properties shows that the main differences in their properties are to do with watershed slopes and sizes. Many studies show that watershed size can be an important factor affecting hydrological responses to land-cover changes (Buttle and Metcalfe, 2000; Blöschl et al., 2007; Zhang and Wei, 2014a; Zhou et al., 2015). A smaller-sized watershed often has less buffering capacity as it may contain fewer heterogeneous landscape components (e.g., wetlands, lakes) and complexities, and as a result, is more sensitive to land-cover changes. In our study, Xiangshui watershed is much smaller than Pingjiang watershed, so a quicker hydrological response should be expected in $\mathrm{Xi}$ angshui watershed. The limited and slower hydrological response in Xiangshui watershed after reforestation as compared with Pingjiang watershed suggests that a factor other than watershed size came into play. Thus, we reasonably judge that the difference in watershed slope between two watersheds is the major factor determining the variations of their hydrological responses. The Xiangshui watershed has a much larger area percentage $(23.9 \%)$ with the slope class $(30-50 \%)$ as compared to that $(4.6 \%)$ in the Pingjiang watershed (Table 1). In southern China where a monsoon climate is dominant, a steeper watershed often has more severe soil erosion if deforestation occurs, and consequently it would take a much longer time to recover through the reforestation process once severe soil erosion occurred (Chen et al., 2002; Zheng et al., 2015).

The importance of watershed properties in hydrological responses to land-cover or forest changes is gradually being recognized in scientific communities. This is particularly relevant for larger watersheds (e.g., $>1000 \mathrm{~km}^{2}$ ) where there are more landforms (e.g., wetlands, lakes), more land 
cover types, and thus more interactions and complexities between various watershed properties. Several studies on forest changes and hydrology in large forested watersheds in British Columbia, Canada, conclude that the effects of forest changes on water are likely watershed-specific (Lin and Wei, 2008; Zhang and Wei, 2014b), which clearly demonstrates the importance of watershed properties in determining the relationship between forest changes and water. However, assessing how watershed properties affect hydrological responses among other key drivers, such as forest change and climate, is a challenging subject. Some studies have applied integrative indicators such as topographic indices (Woods et al., 1997; Hjerdt et al., 2004; Liu et al., 2012) or flow paths and transit time (McGuire and McDonnell, 2006; Soulsby et al., 2009) to assess watershed behaviors or functions, while other studies used a landscape approach (Poff et al., 2006a, b; Price et al., 2011). Nevertheless, more case studies are needed in this direction.

Our results from this study have important management implications. The Pingjiang and Xiangshui watersheds are very important headwater systems to Poyang Lake, the largest freshwater lake in China, which is crucial to sustaining aquatic ecological functions (Guo et al., 2008). Many studies had demonstrated alteration of flow regimes (especially for low and high flows) may be one of the most serious and ongoing threats to the integrity of river ecosystems (Ward et al., 1999; Bunn and Arthington, 2002; Poff and Zimmerman, 2010; Liu et al., 2015b). Therefore, it is highly important to manage flow regimes for sustainable watershed ecosystems in Poyang Lake Basin.

Our results demonstrate a positive effect of reforestation on high and low flows in both Pingjiang and Xiangshui watersheds. This confirms that our reforestation programs implemented over the last decades provide important benefits to restoration of watershed functions in terms of hydrology. More importantly, our study found that hydrological recovery of a steeper watershed likely takes much longer time once it is deforested or damaged, suggesting that we must take extra care when we design management strategies in more sensitive watersheds.

\section{Conclusion}

We found that reforestation decreased high flows, but increased low flows in the watersheds we studied, which is beneficial to the maintenance of aquatic functions and water supply. We also found that there are large variations in hydrological responses to similar reforestation levels, likely due to the difference in watershed properties (e.g., watershed slope). Thus, we conclude that hydrological recovery through reforestation is largely dependant on watershed properties when forest change and climate are similar and comparable.

\section{Data availability}

The climatic and hydrological data used for this paper are not publicly available due to the constraints of governmental policy in China. The data were obtained through a purchasing agreement for this study.

\section{The Supplement related to this article is available online at doi:10.5194/hess-20-4747-2016-supplement.}

Acknowledgements. Funding was provided by Jiangxi Education Department (No. GJJ151141), the National Science Foundation of China (No. 31170665 and No. 31660234), Jiangxi Education Department (KJLD12097 and KJLD14095), Gan-Po 555 Talent Project, and Funding of Jiangxi Province, Scientific Funding by Jiangxi Province (No. 20142BAB214006 and 20161BBH80049).

Edited by: L. Wang

Reviewed by: two anonymous referees

\section{References}

Allan, J. D.: Landscapes and riverscapes: the influence of land use on stream ecosystems, Annu. Rev. Ecol. Evol. Syst., 35, 257284, 2004.

Anderson, M. G. and Kneale, P. E.: The influence of low-angled topography on hillslope soil-water convergence and stream discharge, J. Hydrol., 57, 65-80, 1982.

Bahremand, A., De Smedt, F., Corluy, J., Liu, Y., Poorova, J., Velcicka, L., and Kunikova, E.: WetSpa model application for assessing reforestation impacts on floods in Margecany-Hornad watershed, Slovakia, Water Resour. Manage., 21, 1373-1391, 2007.

Barnes, B. S.: The structure of discharge-recession curves, Eos T. Am. Geophys. Un., 20, 721-725, doi:10.1029/TR020i004p00721, 1939.

Blöschl, G., Ardoin-Bardin, S., Bonell, M., Dorninger, M., Goodrich, D., Gutknecht, D., Matamoros, D., Merz, B., Shand, P., and Szolgay, J.: At what scales do climate variability and land cover change impact on flooding and low flows?, Hydrol. Process., 21, 1241-1247, 2007.

Broomell, S. B., David, V., and Por, H.-H.: Pair-wise comparisons of multiple models, Judgment Decis. Mak., 6, 821-831, 2011.

Bunn, S. E. and Arthington, A. H.: Basic principles and ecological consequences of altered flow regimes for aquatic biodiversity, Environ. Manage., 30, 492-507, 2002.

Buttle, J.: Streamflow response to headwater reforestation in the Ganaraska River basin, southern Ontario, Canada, Hydrol. Process., 25, 3030-3041, 2011.

Buttle, J. and Metcalfe, R.: Boreal forest disturbance and streamflow response, northeastern Ontario, Can. J. Fish. Aquat. Sci., 57, 5-18, 2000.

Chen, S., Hua, L., He, Z., Wei, D., Xiahou, G., and Li, Y.: Effect of soil erosion on soil properties in deep cultivated hill slope in the Loess Plateau, Agro-Environ. Protect., 21, 289-292, 2002. 
Clinton, B. D.: Stream water responses to timber harvest: Riparian buffer width effectiveness, Forest Ecol. Manage., 261, 979-988, 2011.

Eastwood, A., Brooker, R., Irvine, R., Artz, R., Norton, L., Bullock, J., Ross, L., Fielding, D., Ramsay, S., and Roberts, J.: Does nature conservation enhance ecosystem services delivery?, Ecosyst. Serv., 17, 152-162, 2016.

Ford, C. R., Laseter, S. H., Swank, W. T., and Vose, J. M.: Can forest management be used to sustain water-based ecosystem services in the face of climate change?, Ecol. Appl., 21, 2049-2067, 2011.

Gafur, A., Jensen, J. R., Borggaard, O. K., and Petersen, L.: Runoff and losses of soil and nutrients from small watersheds under shifting cultivation (Jhum) in the Chittagong Hill Tracts of Bangladesh, J. Hydrol., 274, 30-46, 2003.

Gao, Z., Zhang, L., Cheng, L., Zhang, X., Cowan, T., Cai, W., and Brutsaert, W.: Groundwater storage trends in the Loess Plateau of China estimated from streamflow records, J. Hydrol., 530, 281290, 2015.

Ge, Y., Jing, T., Liang, C., Wang, X., and Dong, X.: Study on Correlation between Recession Coefficients and Catchment Characteristics in Pearl River, J. China Hydrol., 34, 72-77, 2014.

Gebrehiwot, S. G., Taye, A., and Bishop, K.: Forest cover and stream flow in a headwater of the Blue Nile: complementing observational data analysis with community perception, Ambio, 39, 284-294, 2010

Guo, H., Hu, Q., and Jiang, T.: Annual and seasonal streamflow responses to climate and land-cover changes in the Poyang Lake basin, China, J. Hydrol., 355, 106-122, 2008.

Hjerdt, K., McDonnell, J., Seibert, J., and Rodhe, A.: A new topographic index to quantify downslope controls on local drainage, Water Resour. Res., 40, W05602, doi:10.1029/2004WR003130, 2004.

Huang, L., Shao, Q., and Liu, J.: Forest restoration to achieve both ecological and economic progress, Poyang Lake basin, China, Ecol. Eng., 44, 53-60, 2012.

Iroumé, A. and Palacios, H.: Afforestation and changes in forest composition affect runoff in large river basins with pluvial regime and Mediterranean climate, Chile, J. Hydrol., 505, 113$125,2013$.

Jackson, R. B., Jobbágy, E. G., Avissar, R., Roy, S. B., Barrett, D. J., Cook, C. W., Farley, K. A., Le Maitre, D. C., McCarl, B. A., and Murray, B. C.: Trading water for carbon with biological carbon sequestration, Science, 310, 1944-1947, 2005.

Levy, K. J.: Large-sample pair-wise comparisons involving correlations, proportions, or variances, Psychol. Bull., 82, 177-179, 1975.

Liang, S. and Xiao, Z.: Global land surface products: Leaf area index product data collection (1985-2010), Beijing Normal University, Beijing, 2012.

Lin, Y. and Wei, X.: The impact of large-scale forest harvesting on hydrology in the Willow watershed of Central British Columbia, J. Hydrol., 359, 141-149, 2008.

Liu, J., Chen, X., Wu, J., Zhang, X., Feng, D., and Xu, C.-Y.: Grid parameterization of a conceptual distributed hydrological model through integration of a sub-grid topographic index: necessity and practicability, Hydrolog. Sci. J., 57, 282-297, 2012.

Liu, W., Wei, X., Liu, S., Liu, Y., Fan, H., Zhang, M., Yin, J., and Zhan, M.: How do climate and forest changes affect long-erm streamflow dynamics? A case study in the upper reach of Poyang River basin, Ecohydrology, 8, 46-57, 2015a.

Liu, W., Wei, X., Fan, H., Guo, X., Liu, Y., Zhang, M., and Li, Q.: Response of flow regimes to deforestation and reforestation in a rain-dominated large watershed of subtropical China, Hydrol. Process., 29, 5003-5015, 2015 b.

Llorens, P., Poch, R., Latron, J., and Gallart, F.: Rainfall interception by a Pinus sylvestris forest patch overgrown in a Mediterranean mountainous abandoned area I. Monitoring design and results down to the event scale, J. Hydrol., 199, 331-345, 1997.

Lu, C., Zhao, T., Shi, X., and Cao, S.: Ecological restoration by afforestation may increase groundwater depth and create potentially large ecological and water opportunity costs in arid and semiarid China, J. Clean. Product., doi:10.1016/j.jclepro2016.03.046, online first, 2016.

McGuire, K. J. and McDonnell, J. J.: A review and evaluation of catchment transit time modeling, J. Hydrol., 330, 543-563, 2006.

Nadal-Romero, E., Cammeraat, E., Serrano-Muela, M. P., LanaRenault, N., and Regüés, D.: Hydrological response of an afforested catchment in a Mediterranean humid mountain area: a comparative study with a natural forest, Hydrol. Process., 30, 2717-2733, doi:10.1002/hyp.10820, 2016.

Poff, N. L. and Zimmerman, J. K.: Ecological responses to altered flow regimes: a literature review to inform the science and management of environmental flows, Freshwater Biol., 55, 194-205, 2010.

Poff, N. L., Olden, J. D., Pepin, D. M., and Bledsoe, B. P.: Placing global stream flow variability in geographic and geomorphic contexts, River Res. Appl., 22, 149-166, 2006a.

Poff, N. L., Bledsoe, B. P., and Cuhaciyan, C. O.: Hydrologic variation with land use across the contiguous United States: geomorphic and ecological consequences for stream ecosystems, Geomorphology, 79, 264-285, 2006b.

Price, K., Jackson, C. R., Parker, A. J., Reitan, T., Dowd, J., and Cyterski, M.: Effects of watershed land use and geomorphology on stream low flows during severe drought conditions in the southern Blue Ridge Mountains, Georgia and North Carolina, United States, Water Resour. Res., 47, W02516, doi:10.1029/2010WR009340, 2011.

Schmalz, B., Kuemmerlen, M., Kiesel, J., Cai, Q., Jähnig, S., and Fohrer, N.: Impacts of land use changes on hydrological components and macroinvertebrate distributions in the Poyang lake area, Ecohydrology, 8, 1119-1136, 2014.

Smith, R. and Scott, D.: The effects of afforestation on low flows in various regions of South Africa, Water SA, 18, 185-194, 1992.

Soulsby, C., Tetzlaff, D., and Hrachowitz, M.: Tracers and transit times: windows for viewing catchment scale storage?, Hydrol. Process., 23, 3503-3507, 2009.

Tran, P., Marincioni, F., and Shaw, R.: Catastrophic flood and forest cover change in the Huong river basin, central Viet Nam: A gap between common perceptions and facts, J. Environ. Manage., 91, 2186-2200, 2010.

Troch, P. A., Carrillo, G., Sivapalan, M., Wagener, T., and Sawicz, K.: Climate-vegetation-soil interactions and long-term hydrologic partitioning: signatures of catchment co-evolution, Hydrol. Earth Syst. Sci., 17, 2209-2217, doi:10.5194/hess-17-22092013, 2013. 
Vogel, R. M. and Fennessey, N. M.: Flow-duration curves. I: New interpretation and confidence intervals, J. Water Resour. Pl. Manage., 120, 485-504, 1994.

Ward, J., Tockner, K., and Schiemer, F.: Biodiversity of floodplain river ecosystems: ecotones and connectivity, Regul. Rivers Res. Manage., 15, 125-139, 1999.

Wei, X., Sun, G., Liu, S., Jiang, H., Zhou, G., and Dai, L.: The Forest-Streamflow Relationship in China: A 40-Year Retrospect1, J. Am. Water Resour. Assoc., 44, 1076-1085, 2008.

Woods, R. A., Sivapalan, M., and Robinson, J. S.: Modeling the spatial variability of subsurface runoff using a topographic index, Water Resour. Res., 33, 1061-1073, 1997.

Xiao, Z., Liang, S., Wang, J., Chen, P., Yin, X., Zhang, L., and Song, J.: Use of general regression neural networks for generating the GLASS leaf area index product from time-series MODIS surface reflectance, IEEE T. Geosci. Remote, 52, 209-223, 2014.

Yao, Y., Cai, T., Wei, X., Zhang, M., and Ju, C.: Effect of forest recovery on summer streamflow in small forested watersheds, Northeastern China, Hydrol. Process., 26, 1208-1214, 2012.
Zhang, M. and Wei, X.: Contrasted hydrological responses to forest harvesting in two large neighbouring watersheds in snow hydrology dominant environment: implications for forest management and future forest hydrology studies, Hydrol. Process., 28, 61836195, 2014a.

Zhang, M. and Wei, X.: Alteration of flow regimes caused by largescale forest disturbance: a case study from a large watershed in the interior of British Columbia, Canada, Ecohydrology, 7, 544556,2014 b.

Zheng, L., Zhou, Y., Zhou, X., Li, D., Wu, Z., and Zhou, C.: Recovery Dynamics after Cutting of Forest Ecosystem Services in Mountain, Issues Forest. Econ., 35, 1-6, 2015.

Zhou, G., Wei, X., Luo, Y., Zhang, M., Li, Y., Qiao, Y., Liu, H., and Wang, C.: Forest recovery and river discharge at the regional scale of Guangdong Province, China, Water Resour. Res., 46, W09503, doi:10.1029/2009WR008829, 2010.

Zhou, G., Wei, X., Chen, X., Zhou, P., Liu, X., Xiao, Y., Sun, G., Scott, D. F., Zhou, S., and Han, L.: Global pattern for the effect of climate and land cover on water yield, Nat. Commun., 6, 5918, doi:10.1038/ncomms6918, 2015. 